\title{
MUHAMMADIYAH DAN PENDIDIKAN DI INDONESIA
}

Oleh : Zalik Nuryana, S.Pd.I., M.Pd.I

Pendidikan Agama Islam Universitas Ahmad Dahlan Yogyakarta

Warna pelangi Indonesia tidak bisa terlepas dari salah satu komponen yang bernama Muhammadiyah. Gerakan yang didirikan Ahmad Dahlan pada tahun $1330 \mathrm{H}$ dan bertepatan pada tahun $1912 \mathrm{M}$ ini membawa dampak besar dalam perkembangan sejarah bangsa ini. Fondasi gerakan Muhammadiyah atas telaah Dahlan dalam membaca teks al-Qur'an dan konteks Sosial Kauman saat itu, membawa perubahan besar bagi Indonesia dan Dunia. Sejarawan taufik Abdullah, dalam beberapa kali pertemuan persiapan muktamar 1 abad di Yogyakarta menegaskan bahwa jasa besar yang disumbangkan Muhammadiyah pada bangsa ini adalah berupa "gerakan mencerdaskan kehidupan bangsa" (Mu'arif, 2012: XII)

Abdul Mu'ti dalam prolog Mengokohkan Spirit Muhammadiyah (Farid dkk, 2010: VII) menegaskan bahwa Muhammadiyah adalah gerakan pembaharuan Islam yang bergerak dalam bidang pendidikan, kesehatan, ekonomi, dan pemberdayaan masyarakat. Pembaharuan dalam bidang pendidikan telah dilakukan Muhammadiyah melalui tiga hal, pertama kurikulum. Pendidikan Muhammadiyah mengajarkan studi agama dan studi umum sekaligus, kedua, pembaharuan metode pembelajaran dari paradigma klasik-modern, ketiga, pembaharuan institusional yaitu perpaduan antara sitem pesantren dan sekolah. Pembaharuan itu tentu akan terus dinamis mengikuti perubahan zaman yang serba cepat.

Muhammadiyah menghiasi sejarah panjang negeri ini. Amal usaha Muhammadiyah dalam bidang pendidikan pada tahun 2000 menurut data dari Pimpinan Pusat Muhammadiyah (2010:XII) memiliki capaian yang luar biasa. Jumlah Sekolah Dasar (SD)/MI 2896, Sekolah Menengah Pertama (SMP)/MTs 1.713, Sekolah Menengah Atas (SMA)/SMK/MA 929, Pondok Pesantren 55, dan Perguruan Tinggi Muhammadiyah 132. Capaian ini meningkat dalam kurun waktu 10 tahun, pada tahun 2010 peningkatan pada jenjang Sekolah Dasar (SD) 2604, Sekolah Menengah Pertama (SMP) 1.722, Sekolah Menengah Atas (SMA) 965, Pondok Pesantren 67, dan Perguruan Tinggi Muhammadiyah 151. Bahkan data base Pimpinan Pusat Muhammadiyah menunjukkan kenaikan dari tahun 2010 sampai sekarang yaitu untuk Sekolah Dasar (SD)/MI 2.604, Sekolah Menengah Pertama (SMP)/MTs 1.772, Sekolah Menengah Atas (SMA)/SMK/MA 1.143, Pondok Pesantren 67, Perguruan Tinggi Muhammadiyah 172. Capaian ini jelas secara kuantitas sangat membanggakan. Melihat data di atas, hal ini bisa menjadi tantangan dan peluang. Tantangan untuk meningkatkan kualitas pendidikan Muhammadiyah dan peluang untuk basis perkaderan Muhammadiyah.

Dalam Kurikulum ISMUBA Majelis Pendidikan Dasar dan Menengah DIY (Dikdasmen PWM DIY, 2012:II), pendidikan Muhammadiyah memiliki empat fungsi, yaitu: Pertama sebagai sarana pendidikan dan pencerdasan, Kedua, pelayanan masyarakat, dakwah amar ma'ruf nahi munkar dan Keempat, lahan kaderisasi. Misi pendidikan Muhammadiyah tersebut sekaligus menjadi solusi dan respon terhadap keringnya ruh keagamaan dalam pendidikan, Muhammadiyah memiliki ciri khas yaitu pendidikan al-Islam dan Kemuhammadiyahan. Dua hal itu menjadi ciri khas sekaligus solusi dalam mengisi kekeringan ruh spiritual dalam pendidikan, baik pada pendidikan dasar dan menengah maupun pada pendidikan tinggi di Muhammadiyah. Seluruh Amal Usaha Muhammadiyah (AUM) pendidikan harus melaksanakan pendidikan alIslam dan Kemuhammadiyahan sebagai fondasi pendidikan. AlK yang sudah berjalan pada lembaga Muhammadiyah harus di vitalkan kembali fungsinya. Sehingga empat peran dan misi pendidikan Muhammadiyah dapat berjalan seperti yang di cita-citakan.

\section{ISMUBA/AIK DAN PENDIDIKAN MUHAMMADIYAH}

ISMUBA adalah singkatan dari al-Islam, Kemuhammadiyahan dan Bahasa Arab, sedangkan AIK adalah al-Islam dan Kemuhammadiyahan. Menurut Farid dkk (2010: 30) wawasan pendidikan Muhammadiyah terdiri dari keislaman, kemuhammadiyahan, kebangsaan, keutuhan, dan keunggulan. Wawasan itu merupakan satu kesatuan integral yang patut dikembangkan di setiap lembaga pendidikan Muhammadiyah. Pendidikan Muhammadiyah memerlukan transformasi, tidak cukup hanya inovasi (Zamroni, 2014: 84). Bagian dari tubuh revitalisasi, Pembelajaran AlK yang sudah perjalan di Muhammadiyah perlu ditinjau ulang, dari segi konsep, pelaksanaan, sumber daya, dan komponen pendukung (Organisasi Otonom) yang terintegrasi dalam Grand Desain pendidikan Muhammadiyah.

Tantangan pendidikan Muhammadiyah semakin berat, perubahan pendidikan merupakan sebuah keniscayaan. Muhammadiyah tidak boleh terlena dengan romantisme kuantitas AUM Pendidikan.
Pendidikan AlK menjadi ruh pendidikan Muhammadiyah, maka perlu divitalkan fungsinya. Pendidikan Al-Islam diarahkan pada pengenalan, pemahaman dan penghayatan serta pengamalan ajaran Islam yang menekankan keseimbangan, keselarasan, dan keserasian hubungan manusia dengan Allah Swt, hubungan manusia dengan sesama manusia, hubungan manusia dengan diri sendiri dan hubungan manusia dengan alam sekitarnya sesuai dengan Al-Qur'an dan As-Sunnah. Pendidikan Kemuhammadiyahan diarahkan pada pemahaman dasar-dasar gerakan dan ideologi Muhammadiyah, seperti tafsir Muqaddimah Anggaran Dasar, Matan Keyakinan dan Cita-cita Hidup (MKCH), Khittah Perjuangan, Kepribadian Muhammadiyah dan Pedoman Hidup Islami Warga Muhammadiyah (PHIWM), serta pengenalan, pemahaman, penghayatan dan partisipasi aktif peserta didik dalam berbagai gerakan dan kegiatan Muhammadiyah (KTSP Dikdasmen PWM DIY: 4). Dalam pendidikan tinggi kiranya perlu juga diberikan pemahaman tentang Islam Interdisipliner dalam kerangka pendidikan Muhammadiyah, yang diajarkan kepada mahasiswa. Islam Interdisipliner membangun kerangka paradigma Islam dalam masingmasing jurusan. Sehingga semua jurusan diperguruan tinggi punya wawasan yang luas dalam memandang Islam.

\section{REVITALISASI ISMUBA/AIK}

Ahmad Dahlan bukan mengembangkan system, akan tetapi mengembangkan etos kerja yang berdasarkan pada prinsip-prinsip ajaran Islam. Ahmad Dahlan bukanlah bermaksud mewariskan "sistem pendidikan", tetapi mewariskan etos pembaharuan pendidikan. Oleh karena itu yang penting untuk diwarisi adalah etos pembaharuannya, bukan sekedar sistem pendidikannya (Mohamad Ali, 2010: 10). Etos pembaharuan pendidikan Muhammadiyah seperti yang telah dijelaskan di atas, harus dikawal dan dilaksanakan. AlK merupakan buah dari manisnya pemikiran pembaharuan pendidikan Muhammadiyah. M. Ali menjelaskan bahwa arah pengembangan pendidikan Muhammadiyah memiliki dua jurusan, yaitu pengembangan fondasional-konseptual dan pengembangan praksis pendidikan yang dilakukan oleh praktisi di lapangan. Maka arah revitalisasi pendidikan Muhammadiyah juga mencakup dua hal itu. Konseptual sebagai fondasi dan pengembangan praktis sebagai implementasi dan penguatan AIK pada perguruan Muhammadiyah.

Pendidikan Muhammadiyah diarahkan menjadi pendidikan yang menghidupkan. Pendidikan yang dapat mengatasi permasalahan yang dihadapi ummat manusia. Selama pendidikan tidak diarahkan untuk menghadapi masalah manusia, maka pendidikan itu tidak akan banyak gunanya (Sutrisno, 2008: 52). Revitalisasi AlK diharapkan mampu menjadikan pendidikan Muhammadiyah yang mengidupkan. Dua kerangka dasar dalam penyusunan landasan dan praktis revitalisasi AIK mencakup : Pertama, kesadaran visi-misi pendidikan Muhammadiyah, Kedua, Penguatan Sumber daya manusia. Banyak faktor yang akan mempengaruhi revitalisasi ini, akan tetapi dalam makalah ini penulis menyampaikan hal yang paling mendasar sebagai fondasi revitalisasi.

\section{KESIMPULAN}

Muhammadiyah adalah organisi terbesar di Indonesia dengan jumlah amal usaha dalam bidang pendidikan yang banyak. Banyaknya perguraun Muhammadiyah ini menjadi peluang sekaligus tantangan untuk mengelolanya. Pendidikan yang sudah berjalan ini perlu dikuatkan kembali fungsinya. Pendidikan Muhammadiyah memiliki empat dasar semangat yaitu, pendidikan, pelayanan, dakwah, dan perkaderan. Empat semangat itu yang tidak boleh padam. Pendidikan sebagai pelayanan dan pendidikan dan juga tidak mengesampingkan fungsi dakwah dan perkaderan.

Revitalisasi AIK didasari oleh realitas yang menganggap kurang begitu pentingnya AlK di pendidikan Muhammadiyah. semangat yang kian melemah itu perlu segera kita respon positif. Revitalissi berarti, pertama, mengadakan AIK bagi yang di perguruan Muhammadiyah belum ada, kedua, memvitalkan kembali fungsi AlK yang sudah berjalan. Dengan mempertimbangkan beberapa aspek. Tujuan pendidikan Muhammadiyah yang dalam grand Desain rencana yang akan mendorong terwujudnya Indonesia yang berkemajuan harus dimulai dengan revitalisasi AIK di perguraun Muhammadiyah. 